Journal of Management and Economic
Studies
2019, 1(4): 42-54 DOI: $10.26677 / \mathrm{TR} 1010.2019 .117$
Journal Homepage: https://www.jomaes.org

\title{
The Effect of Wrongful Dismissal on Organisational Performance
}

\author{
A. N. Ezeabaogu \\ Department of Management, University of Nigeria, Enugu Campus, Nigeria
}

\section{B. A. Chukwu}

Department of Business Administration, Igbinedion University, Okada,Edo State, Nigeria. benedictchukwu103@yahoo.com

\section{S. M. Aguwamba}

Department of Business Administration, Igbinedion University, Okada, Edo State, Nigeria.

\begin{abstract}
This study examined the effect of wrongful dismissal on organizational performance Dismissed employees institute court action against employer when dismissal fail to follow laid down procedure in contract arrangement. There must be grounds for dismissal and dismissal must be fair otherwise the employee will seek retribution in court. Dismissal without laid down procedure has costed industries in Nigeria huge sum of money in financing litigations. Litigations has negative impact on the financial status and performance of organizations. This study adopted a survey research design. It involves collection of data from respondents through questionnaire to test hypotheses. Multiple regression technique was used to test hypotheses. The research findings show that a significant and negative relationship lies between the independent variables, instituting court action, stress in initiating dismissal, financial losses from litigation, cost of training replacements and dependent variable organizational performance. All the independent variables have no statistically significant $t$-ratio and have negative relationship with organizational performance. The result is consistent with the literature. The study recommended that there should be compliance to contract arrangement stated by the employer when effecting dismissal, otherwise the dismissal will be deemed unfair and employee will seek retribution in court. And that decision to dismiss should be reviewed by the person responsible for appraising employee, next higher authority and a human resource manager before any action is taken.
\end{abstract}

Keywords: Employee Dismissal, Court Action, Litigation, Contract Arrangement, Dismissal Procedure, Organizational Performance. 


\section{INTRODUCTION}

Wrongful dismissal of employee is not the best for any establishment because of the attendant drawback in terms of productively and growth. Dismissal without recourse to lay down procedure can lead to litigations which can retrogress the progress of the company. Costs awarded to individual seeking redress in court against wrongful dismissal can affect an organization financially and lead to poor performance.

Labour turnover associated with dismissal has direct cost and indirect cost. The direct costs include such items like recruitment, hiring and training replacements. The indirect costs include loss production, work disruption, increased scrap and overtime for other employee in order to meet deadlines (Johnson, 2006; Gustafson, 2002; Meaghan \& Nick, 2002).

Dismissal as part of labour turnover can disrupt organizational strategic planning to achieve its objective when critical employee is lost (Capelli, 2008; Oluwafemi, 2010). Dismissal apart from its cost implication can cause leakage of vital information to competitors by the departing staff as one of the consequences of labour turnover (Ubeku, 1975). He also emphasized that the training given to the departing staff may not be realized and that this might encourage other staff in the organization to resign their appointment for other establishment.

Dismissal is initiated by the employer when all practical steps to rehabilitate employee fail. The grounds for dismissal are misconduct, lack of qualification for the job. insubordination and unsatisfactory performance (Famularo, 1972). Employers no longer find it easy to dismiss an employee since aggrieved employees take them to court. A lot of effort and money is wasted on litigations as a result of wrongful dismissal.

The numerous problems associated with dismissal makes it imperative that one should know the effect of wrongful dismissal in organization. This is one of the reasons why this study is worthwhile.

Dismissing an employee is one of the most crucial tasks a manager faces in the organization. Duham (2001) found that dismissed employee even if forewarned may still react with disbelief or even violence. He emphasized that managers executing dismissal need protection from violence. In a space of five years period physicians in the United States of America interviewed 791 employees who had undergone heart attack to discover what might have caused them. The researchers discovered that the stress associated with firing someone doubled the usual risk of a heart attack for the person firing, during the week following dismissal (Miami Herald, 1998).

Employees feel that their dismissal is fair when multistep procedure such as warning and neutral appeal process is instituted (Connie, 1999;Klass\& Dell' Omo. 1997; Wood Ward, 2007). They also stated that employee feel fairly treated when given full explanations on why and how termination decisions were made. And that they were more likely to perceive layoff as fair, endorse terminating organization and indicate that they will not take the past employer to court.

\section{Objectives of the Study}

The objective of the study is to examine the effect of wrongful dismissal on organization performance. The specific objective of the study is to:

i. Ascertain the extent to which instituting court action by dismissed employee affect organizational performance.

ii. Determine the extent to which stress from initiating dismissal affect organizational performance 
iii. Examine the extent to which financial losses from litigation by dismissed employee affect organizational performance

iv. Evaluate the extent to which costs of hiring and training replacements of dismissed employee affect organizational performance.

\section{Hypotheses of the study}

The following null hypotheses were formulated to guide this study.

Ho1: Instituting court action by dismissed employee does not positively affect organizational performance

Ho2: Stress from initiating dismissal does not positively affect organizational performance.

Ho3:Financial losses from litigation by dismissed employee does not positively affect organizational performance,

Ho4: Cost of hiring and training replacements of dismissed employees do not positively affect organizational performance.

\section{Significance of the study}

The study would be of great benefit to the following stakeholders.

Managers,

The study would be of great benefit to manager who institute dismissal to find possible strategies to avoid wrongful employee dismissal. It would be of great interest and valuable to practicing managers especially Human Resource Managers and help them to avoid wrongful dismissal and create savings in hiring and training replacements.

Researchers and Academia

This would be of great benefit to researcher in business administration and management related field as it would provide empirical evidence for further studies on area of employee dismissal.

\section{Government}

It would be relevant to government and to other agencies on those behaviours, organizational culture and organizational structure that affects employee dismissal. It would help these stakeholders to address the issue of dismissal and to follow the laid down procedure in contractual agreement when effecting dismissal.

\section{Scope of the Study}

The study examined the effect of wrongful dismissal of employees in textile Industry in Nigeria. The scope of this study would delimit to staff of Afprint PLC and Enpee PLC Lagos Nigeria. The population of the study cut across the two textile industries. The study adopted a survey research design through the administration of structured questionnaire raised on a five point Likert Scale to the sampled respondents studied.

\section{LITERATURE REVIEW}

\section{The conceptual review}

\section{Dismissal}

Dismissal are terminations initiated by employer. It is the most drastic step an employer take towards an employee and such an action is given careful consideration (Dessler, 2008). With a contract either the employer or employee could terminate at will the employment relationship. 
The employee can resign for any reason at will and the employer can dismiss an employee for any reason at will (Muhl, 2001).

Dismissal is initiated by the employer when all practical steps to rehabilitate employee fail. (Famularo, 1972).Wrongful dismissal is dismissal that did not comply with the contractual arrangement stated by the employer.

\section{Theoretical Review}

The reasons for dismissal include misconduct, lack of qualification for the job, change requirement of the job and unsatisfactory performance (Famularo, 1972; Flyn, 2000). Miscon duct is wilful violation of the company rule and includes rowdy behaviour, insubordination, stealing, chronic tardiness and poor quality work, while things like stealing, chronic tardiness, absenteeism and poor quality work are easily understood grounds of dismissal, insubordination is not easy to translate into words. The following facts are regarded as insubordination, direct disregard of boss authority, disobedience, defiance of stated company policies, rules and regulations, procedures, public criticism of boss, disregard of reasonable instruction, contemptuous display of disrespect, disregard of chains of command, undermining leadership and insolence comment (Famaluro, 1976).

Unsatisfactory Performance is persistent failing to perform assigned duties to meet prescribed standard, some of the reasons could be due to absenteeism, tardiness and adverse attitude toward the company or fellow employee. Lack of qualification for the job is an employee inability to perform the assigned duty even though he is diligent. The employer should assign the person to another job that he can do or retrain him. Change requirement of the job is the inability of the employee to do the job after employer have changed the nature of the job. The employer should retain or transfer the employee (Famularo, 1972).

Dismissal should follow laid down procedure otherwise, aggrieved dismissed employee will seek redress in court. Wrongful dismissal is a dismissal that failed to comply with contracted arrangement stated by the employer in the employee manual. It refers to a dismissal that violate the law (Lanza\& Warren, 2005). Dismissal without recourse to laid down procedure, can lead to series of litigations which can retrogress the progress of the company. Costs awarded to individual seeking redress in court against wrongful dismissal can affect an organization financially and lead to poor performance. Wrongful dismissal is not the best for any establishment because of the attendant drawback in terms of productivity and growth. (Lanza\& Warren, 2005).

As earlier stated wrongful dismissal happens when an employee's dismissal does not comply with the law or with the contractual arrangement stated by the employer. In a constructive discharge claim due to wrongful dismissal, the plaintiff argues that he or she quit, but had no choice because the employer made the situation so intolerable at work (Falcon, 2001).Avoiding wrongful discharge suit require a two-pronged approach (Coil \& Rice, 1994; Conner, 2000; Sosnin. 2005). They emphasized that people who are fired and who walk away feeling embarrassed or treated unfairly are more likely to seek retribution in court. According to them employers can use severance pay to blunt a dismissal string. There is no way to make termination pleasant, but the first line of defence is to handle it with fairness and justice.

There is never a time dismissal is pleasant but there are several things you do to ensure that the employee view the dismissal as fair (Connie, 1999; Klass and Dell' Omo, 1997; Woodward, 2007). These authors found that "individual who reported that they were given full explanations why and how termination decision were made were more likely to perceive their layoff as fair, endorse terminating organization and indicate that they will not take the past 
employer to court. They found that initiating a formal multistep procedure (including warning and neutral appeal process also fosters fairness.

Who actually does the dismissal is important. Employees in a study whose managers inform them of an impending layoff viewed the dismissal procedure as much fairer than those told by, say a human resource manager. The quality of the pre-layoff relationship between the employee and manager did affect whether or not the employee preferred to get the news from the managers. Based on this, one has questioned the common practice of having the Human Resource Department handle such modification (Connie, 1999).

Dismissing an employee is one of the crucial tasks a manager faces in the organization. In a space of five years period, physician in the United States of America interviewed 791 employees who had undergone heart attack to discover what might have caused them. The researchers discovered that the stress associated with firing someone doubled the usual risk of a heart attack for the person firing during the week following the dismissal (Miami herald, 1998).

Duham (2001) found that dismissed employee, even if forewarned or warned many times, may still react with disbelief or even violence. He emphasized that the manager executing dismissal need protection from violence. Facility security measures are important wherever dismissal occur. Checklists are used to ensure that dismissed employee returned all keys and company property, and often accompanying them out of their offices and out of the building (Dessler, 2008).

The employer should disable internet - related passwords and account of former employee, plug hole that could allow an ex - employee to exploit someone else's user account to gain illegal access, and have formal rules to return company laptops (Jaikmur, 2001). The person's immediate supervisor should ensure that all access privileges are cut off and all account detected, the company security group checks to make sure the manager follow the procedure (Jaikmur, 2001). Dismissal is an involuntary turnover. Involuntary turnover occurs where the employee is terminated by the employer but has no choice in their termination (Both \&Hamer, 2007). Involuntary turnover includes death, retirement and dismissal (Griffith, Hom\&Gartner, 2003).

Johnson (2006) noted that employee turnover costs organizations approximately 50 percent of their salary in recruiting and training replacements. Chukwu, Josiah,Ogungbenle and Akpeti (2012) also stated that organization incur costs in hiring and training replacement as a result of labour turnover. Other costs associated with turnover includes lost production, lost sales and management time and loss attached to intellectual capital (Gustatson, 2002; Meaghan \& Nick, 2002). Dismissal is part of involuntary labour turnover and direct and indirect costs are also incurred when one is dismissed. Dismissal can disrupt organization strategic planning to achieve its objective when critical employee is lost (Oluwafemi, 2010; Capeilli; 2008; Griffeth et al 2003).Dismissal apart from its cost implication, Ubeku (1975) stated leakage of vital information to competitors by the departing staff as one of the consequences of labour turnover (dismissal). He also emphasized that the training given to the departing staff may not be realized and that this might encourage other staff in the organization to resign their appointment for other establishments.

\section{METHODOLOGY}

Survey research design was used to gather information or data from sample oftextile companies in Nigeria. The population of the study comprises staff of Afprint Plc and Enpee Plc Lagos, Nigeria. The population of the study was 1753. A sample of 326 was selected for the study using Yamane (1964) formular. A stratified random sampling technique was used to distribute sample 
to Afprint Plc and Enpee Plc using stratum allocation technique of Kumar (1976).Sampling was conducted on 326 respondents using questionnaire instrument. The questionnaire was made up of 5 points Likert scale. For each variable, there were four (items/elements) which were deployed keeping in view of the questionnaire filling culture and understanding of the population. The questionnaire is a self development of items. The demographic data was part of the questionnaire.

A total of 326 questionnaires were distributed to staff of Afprint Plc and Enpee Plc and 268 responses were collected which has $82.21 \%$ response rate. There were five variables in total in the model of study where there are four independent variables and one dependent variable. The independent variables are instituting court action, stress in instituting dismissal, financial losses from litigation, and cost of hiring and training replacements and one dependent variable organization performance. As the data consists of single dependent variable and multiple independent variables, multiple regression analysis were deployed and SPSS 16.0 was used to generate results. Descriptive method of analysis were utilized to analyze data from questionnaire instrument using percentages. Hypotheses testing were carried out using multiple regression statistics.

\section{Validity and Reliability of Instrument}

\section{Pilot Test}

A pilot test was carried on 50 respondents before questionnaire distribution in other to collect their comments, ensure simplicity and understanding of questionnaire, which helped in developing the questionnaire more efficiently. A favourable comment was obtained from the 50 respondents and the results of the pilot test ensure that the survey was understandable by the 50 respondents.

The reliability analysis was conducted on instituting court action, stressin instituting dismissal, financial lossfrom litigationandcost of hiring and training replacements. Table 1 showed the reliability analysis of the questionnaire, and the results showed that the reliability coefficient of the questionnaire rangedfrom $0.715-0.920$. The reliability coefficient of the questionnaire was 0.822 ,this means that the data collected were valid and reliable enough to be used for analysis. Walonick (1993) stated that the values above 0.7 are considered acceptable, and the values above 0.8 are preferable or good

Table I Results of Reliability Analysis

\begin{tabular}{|llc|}
\hline Variables & Items & Cronbach's Alpha \\
\hline Instituting court action & 4 & 0.715 \\
\hline Stress in instituting dismissal & 4 & 0.880 \\
\hline Financial losses from litigation & 4 & 0.810 \\
\hline Cost of hiring and training replacements & 4 & 0.786 \\
\hline Organizational Performance & 4 & 0.920 \\
\hline
\end{tabular}

Source: Researchers computation: 2018

\section{Model Specification}

In order to determine the effect of dismissal on organizational performance, a multiple regression model is used. The regression model used is specified as follow.

$\mathrm{OP}=\beta \mathrm{O}+\beta_{1} \mathrm{ICA}+\beta_{2} \mathrm{SID} \beta_{3} \mathrm{FLL} \beta_{4} \mathrm{CHTR}+\mu$

Where 
$\mathrm{OP}=$ Organizational Performance

ICA= Instituting Court Action

$\mathrm{SID}=$ Stress in instituting dismissal

FLL= Financial Losses from Litigation

$\mathrm{CHTR}=$ Cost of Hiring and Training Replacements

$\beta \mathrm{o}=($ Beta Zero) $\mathrm{y}$-intercept of the line

$\beta_{\mathrm{i}}=(\mathrm{i}=1,2,3,4)$ are estimates of the coefficient.

$\mu=$ an error term measuring variables in turnover intention unaccounted for by the independent variables.

\section{DATA PRESENTATION AND, ANALYSIS FOR SAMPLE BACKGROUND VARIABLES}

A total of three hundred and twenty six (326) questionnaire were given out to respondents and two hundred and sixty eight (268) were duely returned and useable, and subsequently analyzed. Therefore, the response rate was $82.21 \%$. The demography of the respondents was presented in table 2.

Table 2: Demography of Respondents

\begin{tabular}{|l|l|l|}
\hline Responses & Frequency & Percentage (\%) \\
\hline Age: Below 30 years & 54 & 20.1 \\
30-39 years & 116 & 43.3 \\
40-49 years & 70 & 26.1 \\
50 years and above & 28 & 10.5 \\
Total & 268 & 100.0 \\
\hline Sex: & 188 & \\
Male & 80 & 70.1 \\
Female & 268 & 29.9 \\
Total & & 100.0 \\
\hline Education level: & 74 & \\
Secondary & 110 & 27.6 \\
Post-secondary & 84 & 41.0 \\
Polytechnic/university & 268 & 31.4 \\
Total & & 100.0 \\
\hline Department: & 61 & \\
Administration & 77 & 22.8 \\
Marketing & 130 & 28.7 \\
Production & 268 & 48.5 \\
Total & & 100.0 \\
\hline Marital Status & 85 & 31.7 \\
Single & 183 & 68.3 \\
Married & 268 & 100.0 \\
Total & & \\
& & \\
\hline Source: Field Survey, 2018 & & \\
\hline
\end{tabular}

Source: Field Survey, 2018

Table 2 above shows the age distribution of the sampled respondents of whom $54(20.1 \%)$ of them were aged 30years below, $116(43.3 \%)$ of them were aged $30-39$ years, $70(26.1 \%)$ of them 
were aged 40-49years and $28(10.5 \%)$ of them were aged 50years and above. This shows that the majority of the respondents aged $30-39$ years. On the issue of sex of the sampled respondents, $188(70.1 \%)$ were males and $80(29.9 \%)$ were females. This implies that majority of the respondents were males. On the educational level of the respondents who returned valid copies of distributed questionnaires of whom $74(27.6 \%)$ of them attended secondary school, 110 $(41.0 \%)$ of them attended post secondary school and $84(31.4 \%)$ of them attended polytechnic/university. This means that majority of the sampled respondents attended postsecondary school. Based on department, $61(22.8 \%)$ of the respondents were in administration department, $77(28.7 \%)$ of the respondents were in marketing department, 130 (48.5\%) of the respondents were in production department. This means that majority of the respondent were in production department. On the issue of marital status of the sampled respondents, 85 (31.7\%) of them were single and $183(68.3 \%)$ of them were married. This shows that the majority of the respondents were married.

Presentation of Data Collected and used for Regression Analysis

Table 3: Distribution of Responses to Questions on Independent Variables

\begin{tabular}{|c|c|c|c|c|c|}
\hline Variables & $\begin{array}{l}\text { Strongly } \\
\text { Agree }\end{array}$ & Agree & Undecided & Disagree & $\begin{array}{l}\text { Strongly } \\
\text { Disagree }\end{array}$ \\
\hline 1. ICA & $16(6)$ & 27 (10.1) & $11(4.1)$ & $129(48.1)$ & 85 (31.7) \\
\hline 2. SID & $21(7.8)$ & 30 (11.2) & $12(4.5)$ & $124(46.3)$ & $81(30.2)$ \\
\hline 3. FLL & $29(10.8)$ & 38 (14.2) & $15(5.6)$ & $90(33.6)$ & $96(35.8)$ \\
\hline 4. CHTR & $13(4.9)$ & $52(19.4)$ & $13(4.8)$ & $119(44.4)$ & $71(26.5)$ \\
\hline
\end{tabular}

Source: Field Survey, 2018

Where

ICA = Instituting Court Action

SID $=$ Stress in Initiating Dismissal

FLL $=$ Financial Losses from Litigation

CHTR $=$ Cost of Hiring and Training Replacements

Figure's that are not in bracket show the number of responses, while those that are in bracket show the percentages of responses

Table 4: Distribution of responses to questions on dependent variable

\begin{tabular}{|l|l|l|l|l|l|}
\hline Dependent Variable & $\begin{array}{l}\text { Strongly } \\
\text { Agree }\end{array}$ & Agree & Undecided & Disagree & $\begin{array}{l}\text { Strongly } \\
\text { Disagree }\end{array}$ \\
\hline $\begin{array}{l}\text { Organizational } \\
\text { Performance }\end{array}$ & $\begin{array}{l}57 \\
(21.3)\end{array}$ & $\begin{array}{l}116 \\
(43.3)\end{array}$ & $\begin{array}{l}53 \\
(19.8)\end{array}$ & $\begin{array}{l}(10.4) \\
\text { (5) }\end{array}$ & \begin{tabular}{l}
$(5.2)$ \\
\hline
\end{tabular}
\end{tabular}

Source field survey, 2018

Figures that are not in bracket show the number of responses and while those that are in bracket show the percentages of the responses.

\section{Multiple Regression Technique}

The study employed multiple regression technique to test the formulated hypotheses given the individualsignificance of the variables and the results were presented in table 5 below. 
Table 5 Multiple Regression Result

\begin{tabular}{|l|l|l|l|l|}
\hline Variables & Coefficient & Std. Error & t-Statistics & Problem \\
\hline Constant & 3.856 & 0.632 & 6.096 & .000 \\
ICA & -0.612 & 0.093 & -6.554 & .003 \\
SID & -0.432 & 0.090 & -4.798 & .005 \\
FLL & -0.448 & 0.067 & -6.669 & .001 \\
CHTR & -0.678 & 0.097 & -6.978 & .003 \\
\hline
\end{tabular}

$\mathrm{R}^{2} 0.603$

$\mathrm{R}^{2}$ Adjusted 0.598

Std. Error 0.412

F- Statistics 26.561[.001

Interpretation of Result

Test of hypothesis

Hypothesis 1: Instituting court action by dismissed employee does not positively affect organizational performance

The beta value shows that 1 unit negative change in the value of instituting court action by dismissed employee would result in -0.612 units (61.2\%) negative change in organizational performance, other variables being held constant. This in essence entails that instituting court action is a function of organizational performance. Instituting court action show statistically significant unique contribution in explaining organizational performance with $(\mathrm{P}<.01)$. While $\mathrm{t}-$ statistics of instituting court action account for significant negative variation in dependent variable, that is organizational performance $(t=-6.554, \mathrm{P}<.01)$. Resultantly null hypothesis is accepted and alternate hypothesis is rejected, meaning that instituting court action exerts significant effect on organizational performance and have negative relationship with organizational performance. This result aligns with the theory which states that it is no longer easy to dismiss employee since they always seek redress in court by instituting court action against the employer. Labour laws and court ruling have increasingly limited management right to dismiss employee

Hypothesis 2: Stress from initiating dismissal does not positively affect organizational performance

The beta value shows thatlunit negative change in the value of stress from initiating dismissal would result in -0.432 units $(43.2 \%)$ negative change in organizational performance, other variables being held constant. This in essence entails that stress from initiating dismissal show statistically significant unique contribution in explaining organizational performance with $(\mathrm{P}<0.1)$, while $\mathrm{t}$-statistics of stress from initiating dismissal account for significant negative variation in dependent variable, that is organizational performance $(\mathrm{t}=-4.798, \mathrm{P}<.01)$. Resultantly null hypothesis is accepted and the alternate hypothesis rejected, meaning that stress from initiating dismissal exerts significant effect on organizational performance and have negative relationship with organizational performance.This result accords with the theory which states that dismissing an employee is one of the most crucial task a manager faces in organization. Research have discovered that the stress associated with dismissing someone doubled the usual 
risk of a heart attack for the person executing dismissal, during the week following the dismissal. Dismissed employee even if forewarned or warned many times may still react with disbelief or even violence.

Hypothesis 3: Financial losses from litigation by dismissed employees does not positively affect organizational performance.

The beta value shows that 1 unit negative change in the value of financial losses from litigation would result in -0.448 units $(44.8 \%)$ negative change in organizational performance, other variables being held constant. This in essence entails that financial losses from litigation is a function of organizational performance. Financial losses from litigation show statistically significant unique contribution in explaining organizational performance with $(\mathrm{P}<.01)$. While $\mathrm{t}-$ statistics of financial losses from litigations account for significant negative variation in dependent variable, that is organizational performance $(\mathrm{t}=-6.669, \mathrm{P}<.01)$. Resultantly null hypothesis is accepted and the alternated hypothesis is rejected, meaning that financial losses from litigation exerts significant impact on organizational performance and have negative relationship with organizational performance. The result aligns with the theory which states that dismissal without recourse to lay down procedure, can lead to series of litigations which can retrogress the progress of the company. Costs awarded to individual seeking redress in court against wrongful dismissal can affect an organization financially and lead to poor performance.

Hypothesis 4: Costs of hiring and training replacements of dismissed employees do not positively affect organizational performance.

The beta value shows that 1 unit change in the value of cost of hiring and training replacement of dismissed employees would result in -0.678 units $(67.8 \%)$ negative change in organizational performance, other variables being held constant. This in essence entails that cost of hiring and training replacements is a function of organizational performance. Cost of hiring and training replacements show statistically significant unique contribution in explaining organizational performance with $(\mathrm{P}<.01)$. While $\mathrm{t}$-statistics of cost of hiring and training replacement account for significant negative variation in dependent variable that is organizational performance $(t=-$ $6.978, \mathrm{P}<.01$ ). Resultantly null hypothesis is accepted and the alternate hypothesis is rejected, meaning that cost of hiring and training replacement exerts significant effect on organizational performance and have negative relationship with organizational performance. This result accords with the theory which states that labour turnover associated with dismissal has direct and indirect costs. The direct costs include such items like recruitment, hiring and training replacements. The indirect costs include loss production, work disruption, increased scrap and overtime for other employee in order to meet deadline.

\section{DISCUSSION OF FINDINGS}

Considering the results obtained in table 5 , the individual $\beta$ in case of each and every variable indicates negative result over all. Negative relationship lie between the independent variable instituting court action and the dependent variable organizational performance. This is consistent with the researches of Coil and Rice (1994); Conner (2000); Sosnin (2005).

Negative relationship also exists between the independent variable stress in initiating dismissal and the dependent variable organizational performance. This is consistent with the researches of Miami Herald (1998); Duham (2001).

There is a negative relationship between the independent variable financial losses from litigation and the dependent variable organizational performance. This is consistent with the researches of Warren (2005); Sosnin (2005) Conner (2000); Coil and Rice (1994). 
A negative relationship exit between the independent variable cost of hiring and training replacement and the dependent variable organizational performance. This is consistent with the researches of Johnson (2006); Chukwu et al (2012).

The whole analysis show that the independent variables, instituting court action, stress in initiating dismissal, financial losses from litigation and cost of hiring and training replacements regressed organizational performance and provide a considerable outcome where significant value ( $p$ ) is less than $0.01 ; \mathrm{F}$ value equal to 26.561 , shows that the model has overall significance at $1 \%$ level. $\mathrm{R}^{2} .603$ suggests that the model has a good fit. This indicates that $60.3 \%$ of variation in organizational performance is accounted for by variation in explanatory variables, suggesting that the model has a good explanatory power on the changes in organizational performance among variables.

\section{Conclusion}

The objective of this study is to examine the effect of wrongful dismissal on organizational performance. To execute this research goal, four objectives were raised and four hypotheses were also formulated and tested. Based on the results from the test of the four hypotheses, it is concluded that wrongful dismissal have significant and negative relationship with organizational performance. And the organizations should comply with the company rules, regulations and contract arrangement stated by the employer before effecting dismissal.

\section{Recommendation Based on Research Findings}

1. It is recommend that there should be compliance to the contract arrangement stated by the employer when effecting dismissal, otherwise the dismissal will be deemed unfair and employees will seek retribution in court.

2. It is recommend that the reason for dismissal should be clearly stated and should be based on company rules and regulations and full explanation on why and how decision was made.

3. It is recommended that the decision to dismiss should be reviewed by the person responsible for appraising employee and he should get approval from the next higher authority, where there is a human resource manager, he too should be consulted before every action is taken.

4. It is recommended that the security and comfort of the manager conducting dismissal must be ensured; otherwise subsequent dismissal will stumble and fail, since manager will be afraid of continuing the exercise.

\section{Limitations of the study}

In carrying out this study, the researcher was faced with the following limitations.

1. The sample size of the study was constrained due to the inability of the respondents to voluntarily participate in the survey

2. The usage of research instrument was usually constraint with poor response and this ultimately affects the sample size. Also the reluctant of respondents to answer the questionnaire in the process of data collection, due to fear of victimization by those in Authority was another limitation of the study.

3. Statistical modelling of the variables (court action, stress, financial losses and cost of hiring and training replacements was tedious to the researcher. Therefore the technical nature of the study also limits the study under investigation. 


\section{REFERENCE}

Both, S \& Harmer, R (2007) Labour turnover in the retail industry.The International Journal of Retail Distribution Management 35, 289-300.

Capelli, P (2008) Talent on Demand Management, Talent Age of Uncertainty, Boston HarvardBusiness Press.

Chukwu, B.A, Josiah, M, Ogungbenle, S.K \&Apketi, E (2012) The Effect of labour turnover in Brewery Industries in Nigeria: A study of Guinness Brewery Industry PLC and Bendel Brewery LTD in Benin City. Asian Journal of Business Management 4, 114- 123.

Coil, J \& Rice C (1994) Three step to creating effective employee releases, Employment Relations Today pp 91-94.

Conner, J (2000) Disarming terminated employees, Human Resource Magazine pp. 113-116

Connie, W (1999) Perceived unfairness of layoffs among individuals who have been laid off. A longitudinal study, Personal Psychology 2, 55-54.

Dessler G (2008) Human Resource Management.11 th Ed. NJ.Pearson Prentice Hall Upper Saddle River.

Duham, K (2001) The kinder gentler way to layoff employees-more human approach helps, Wall Street Journal P.B-1

Falcon P (2001) Give employee the gentle hook. Human Resource Magazine pp 121-128.

Famularo, J (1972) Hand Book of Modern Personal Administration. New York Mcgraw-Hill.

Flynn, G (2000) Grounds for dismissal, workforce 79, 86-90.

Griffeth R.W, Hom, P.W \&Gaertner, S (2003). A meta - analysis of antecedents and correlales of employee turnover update, moderating tests and research implications for the next millennium Journal of Management 26, 463-488.

Gustafson, C.M (2002) Staff turnover retention. International Journal of Contemporary Hospitality Management 14, 106-110.

Jaikmur, V (2001) Downsizing leave firms vunerable to digital attacks. Computer World pp.68.

Johnson, G. (2006) The essential impact of context on organizational behaviour. Academy of Management Review 31, 368-408.

Klass, B \& Dell' Omo, G (1997) Managerial use of dismissal.Organizational level determinants.Personnel psychology 1,927-953.

Kumar, S (1976) AManual of sampling Techniques, London, Heinemann.

Lanza, R \& Warren, M (2005) United states: Employment at will prevail despite exception to the rule, Society for Human Resource Management Legal Report pp 1-8.

Meagham, S \& Nick, B (2002) Voluntary turnover: Knowledge management- Trend or Foe? Journal of Intellectual Capital. 3, 3003-320.

Miami Herald (1998) one more heart risk firing employees Miami herald pp. c11-c17.

Muhl, C (2001) The employment at will doctrine; Three major exceptions Monthly Labour Review 124, 3-11. 
Oluwafemi, O.J (2010) Contextual Dispositional Factors, Turnover Intention and Perceived Job Alternative as Predictor of Organization Citizenship Behaviour of Employees of Nigerian's oil Industry University of Ibadan Unpublished Ph.D Thesis.

Sosnin, B (2005) Orderly departures Human Resource Magazine 50, 74-78.

Ubeku .A.K. (1975) Personnel Management in Nigeria, Ethiope publishing company, Benin.

Walonick, D. S (1993). The research process Available at www.slatpac.com/researchpapers/research-processhtm (Accessed: 24 Sept 2010).

Woodward, N.H (2007) Smoother Separation. Human Resource Magazine pp 94-97.

Yamane, Y (1964) Statistics. An Introductory Analysis. New York; Harper and Row. 